\title{
Undermining the Occupation: Women Coalminers in 1940s Japan
}

\author{
Matthew Allen, University of Wollongong
}

\section{Introduction}

During the period from 1943-1945 Japan's big coalmines faced a severe labour shortage. Korean 'colonials' and Chinese and western prisoners of war were brought in to help meet the dire labour shortage in the coalmines created by conscription, and women who had been sorting coal at the pit-top also found themselves pushed into working on the coalface (Sonoda 1970). This signalled a radical change in policy from large mine owners and their labour overseers, who were forced to address a number of overlapping issues: the shortage of male labour; intensive government pressures to maintain production; and an existing culture of women's involvement in the industry over many years, though mainly in gender separated roles - that is, women worked above ground, while men laboured underground. ${ }^{1}$ Pay reflected these circumstances, and men were paid considerably better wages for their work underground. However, because of the wartime labour shortage, women were once more allowed back onto the coalface in 1943 in the large mines. In the smaller companies, they had never disappeared from the pits.

The circumstances were somewhat complicated by the culture of the mines in which the women had been raised. Socialised to acknowledge the hierarchies of work and wages, and the relative gender status that spun from one's work, many women workers were

\footnotetext{
${ }^{1}$ Women were formally banned from working underground in 1928 during the peak of the prewar coal boom; however many continued to work at the coalface until the end of the war, as we see later in this essay.

PORTAL Journal of Multidisciplinary International Studies, vol. 7, no. 2, July 2010.

Gender and Occupations in the Asia-Pacific, special issue, guest edited by Christine de Matos and Rowena Ward.

ISSN: 1449-2490; http://epress.lib.uts.edu.au/ojs/index.php/portal

PORTAL is published under the auspices of UTSePress, Sydney, Australia.
} 
enthusiastic supporters of the new policies. Pay for working the coalface, although only 80 percent of the men's (Idegawa 2005), was much better than that of the most senior coal sorters, and on top of this, the status that their work generated was irreplaceable. Empowered with money and status, their gender was not necessarily seen as an impediment to their integration higher up the social hierarchy of the coal communities.

This was not the first time, however, that women had worked underground. Indeed, women were actively involved in digging and hauling coal from the industry's earliest days. Women were previously employed as miners in some of the very small 'badger holes' during the prewar years, but it was not until the 1943-1945 period that the largescale deployment of women at the coal face occurred in the larger companies. The work on the coalface, while arduous and unrelenting, was also compelling for many women, who were empowered for the duration of the war. ${ }^{2}$

Following Japan's surrender, it could be expected that the forced labourers would be repatriated, and the women workers would resume their status as coal sorters as men returned from war to take up their former occupations. This did not occur. Repatriation of Korean and other forced labourers was very slow, but, more importantly, the expected influx of former soldiers to work in the mines did not occur immediately. Moreover, poor communications between the Occupation authorities and local governments, inadequate surveillance of the circumstances in the remote coal producing areas, and perhaps most importantly, the Panopticon-like control over people's lives exerted by the mining management and their yakuza labour controllers, prevented significant changes occurring at the workplace in the immediate postwar years in these small and medium sized 'frontier' mines (Allen 2009). Focusing on the women miners in the Chikuhō region of Northern Kyushu, this paper attempts to extract some of the reasons women defied the Occupation, locating this resistance within a complex cultural-historical context.

\section{Women down the mines}

Coalmining was the lifeblood of Japan's economy in the early $20^{\text {th }}$ century. It fuelled Japan's manufacturing industry, military infrastructure, transport infrastructure, and of

\footnotetext{
${ }^{2}$ The large coal companies, despite being large-scale employers that employed up to 3,000 people on-site, only employed 40 percent or so of the coalmining workforce. They were comparatively good employers, offered reasonable company housing, relatively safe working conditions, reasonable pay and conditions, and were very much the employer of choice for miners and their families.
} 
course, its electricity (Samuels 1987). It was also one of the few substantial natural resources that Japan possessed. ${ }^{3}$ Coal's status as a priority industry throughout the fifteen-year war (1931-1945), and its importance to Japan's military and imperial ambitions, ensured that the large companies were closely monitored and engaged by the Japanese state. Mechanisation in the 1920s in the large companies led to a revolution on the workface as traditional mining practices were replaced by more efficient newer methods. The old system typically involved men digging the coal, while women transported it to the surface and sorted it outside the mine. This system was gradually replaced by teams of two men and a digging machine, and increasing automation in recovering the coal. Women retained their pit-top work sorting coal, but did so at 60 percent of men's wages. Following the economic recession of the early $1920 \mathrm{~s}$ - low demand for coal, and competition from overseas led to stockpiling of unsold coal in Japan — women were laid off from their jobs even on the surface, and in 1928 women were formally banned from entering coalmines, even as haulers (Yada 1975).

The coal industry was the largest and most powerful of Japan's few extractive industries, and mining interests were well established in a number of areas of Kyushu and in Hokkaido. By the 1930s the coal industry was structured so that the larger coal companies-Mitsui, Mitsubishi, Sumitomo, Yasuda, Aso (mostly arms of zaibatsu or industrial and financial clique-interests)—were empowered economically and politically. These companies had strong links with government, and were substantive employers, often accommodating thousands of workers and their families in their company housing at the pit tops. In order to counter the labour shortage during the war they 'employed' forced labourers from the colonies, as well as prisoners of war who were deemed able to work in the mines. ${ }^{4}$

The prioritisation of coal production for the war effort led to significant increases in demands for coal output, but the shortage of labour was a problem. From as early as

\footnotetext{
${ }^{3}$ Indeed, so crucial was coal to Japan's economic health that perhaps the most significant reason for the invasion and cooption of Manchuria was to enhance and support coal (and other mineral) production. ${ }^{4}$ In recent years, the Nihonshikai has refuted that there were forced labourers in Japan, and has argued that all labour from overseas was 'voluntary.' Indeed, the difficulty in corroborating the type of labour conducted in the coalmines has led to groups of right-wing academics attempting to rewrite history, focusing on the benevolent use of colonial 'volunteers' and POWs by large coalmining company management. The so-called 'Textbook Revisionist Movement,' informed by authors with right-wing leanings, has in fact claimed that there were no 'forced labourers' in the pits during the war years. This fabrication was supported tacitly by the former Prime Minister (2008-2009), Taro Aso, whose father owned and operated Aso Mining, one of the larger and more violent coalmines.
} 
1943, as the war turned against Japan, fewer prisoners and Koreans were able to be transferred to the coalmines, and the big mines recognised that they needed to supplement their existing labour force with women (Idegawa 2005). In the large companies, women and men worked together on the coalface, with women often working as ato-muki (waste haulers) for men, dragging the waste coal out of the mine in boxes, and supplying the pit-top women with material to be sorted.

In the more remote areas of Chikuhō, in Northern Kyushu, lay smaller, rougher, and more notorious coalmines, which to all intents and purposes were beyond the discourse of the state-which includes physical, ethical, legal, psychological factors, and control over the narratives of belonging - that is, coalminers and their families lived in a culture that bore little resemblance to that of city dwellers at the time. Police had no authority in these mines or the nearby communities, governments turned a blind eye to mining activities, and many small mining towns were dominated by the control the companies and their enforcers extended into the homes of the workers. Many were 'fly-by-night' operations, typically staying in business for a mere two or three years until they exhausted their narrow seams, and employing up to a dozen workers, many of whom were women. Itinerant husband-and-wife teams moved from mine to mine throughout the 1930s, and, indeed, until the end of the war, looking for work and accommodation. Working conditions in these mines were tough:

During the war, when I was working underground, the height of the ceiling was just about 1 尺 5 寸 (just under one metre). I worked 16 or 18 hours a day in that sort of environment. (Tajima 2000: 232)

Even if I went down at 6am with the first shift, sometimes I wasn't able to come back until 1am or 2am. It's not 1 or 2 o'clock in the daytime! Even so, we were told to go into the mine at 6 a.m. the next morning. We went home, had a bath, ate supper, drank a glass of yamizake, then had to get ready to go to work again without having time to sleep. I really wanted to take a day off. But if I didn't turn up, a labour overseer would visit and beat me while I was lying down. (Tajima 2000: 230)

The medium sized companies, while more permanent, operated throughout the war using similar 'traditional' labour control methods, which involved subjecting workers to extremes. That is, the mines were run so that labour was ranked according to nationality and hierarchy: local Japanese men (and their families) were at the top, while Koreans and other forced labourers were at the bottom. Company housing reinforced these relations Japanese and Korean workers were segregated, and the conditions in which the foreign labourers lived were more primitive than those of other miners. To put this in 
perspective, the coal miners were at the bottom of Japan's social hierarchy. They worked long hours in dangerous conditions, were not paid well for their work, lived in dilapidated company housing, and faced violence on a daily basis from the labour overseers, often recruited from the ranks of local organised crime gangs, and disgruntled miners. ${ }^{5}$ The foreign labourers were exposed to extreme behavioural control by labour overseers. They were constantly under the eye of management, who would not relinquish their panopticon-like control of the labour force (Allen 2009).

In contrast to the draconian controls exerted over the mining labour force, management deployed relaxed interpretations of labour laws to allow both child labour and women's labour into the mines. Hashimoto Tameyo, a former miner with one of the smaller mines, said of her wartime experience:

Compared to large mines, the smaller companies didn't have a system of 'application' and anybody could work there. I went underground with my little brother and sister on my back when they needed breast feeding. While my mother was breast feeding them I did her work for her, a kind of ato-muki's job like dragging sura and so on. I was 12 or 13 then. That was the first time I went into the mine. (Tajima 2000: 158)

Hanasaki Kinuyo also went into the mines as a young woman: 'I went into the mine when I was about twelve years old. Officially, you weren't able to apply until fifteen years old but I was physically well built and went down the mine by lying' (quoted in Tajima 2000: 200). Another miner had a slightly more duplicitous experience: 'Actually, I was too young to go into the mine. But it was during the war and they lacked the work force. I borrowed my mum's name and went down' (Tajima 2000: 230).

Being employed on the coalface as diggers and haulers was seen as a 'natural' transition for many women (Idegawa 2005). This was because of the culture in which they had been raised. Moreover, many worked in the mines their whole working lives, and the step up (or down) to the heavy demands of digging and hauling was not impossible to ask of them. Women worked in many occupations below ground: as diggers, haulers, carters, truss engineers, explosive operators, and so on. Able women were often promoted if they were seen to be capable in particular roles; that is, they were given

\footnotetext{
${ }^{5}$ The labour overseers (rōmu kakari) needed to be physically tough in order to maintain discipline with the workers, who were physical, militant, and often resistant to the constant demands of hard physical labour. For more on this, see Allen (2009).
} 
piecework-based salaries at a high percentage of men's rates. ${ }^{6}$

While wages and working conditions were standardised in the large companies, the small companies continued to operate by using the cheaper, less capital-intensive, oldstyle labour practices, and thus continued to employ women down the mines throughout the 1930s and 1940s. Hoshū, in Kawasaki, in the Chikuhō region of Kyushu, for example, employed women as haulers until the early 1950s (Sasaki, 1988). In other words, they defied the state. This situation was tacitly supported by local authorities, who recognised the need for the mines to be economical, and these practices continued to the end of the war. That is, in the smaller coalmines women continued to work at the pit face with men on a daily basis, often for less pay than the men, based on estimations of how much they could produce. The work was hard, but in the absence of other betterpaying work opportunities, many married women worked on the coalface for up to ten years. Tsumuru Setsu, a miner in a medium sized mine, described her experiences:

I went underground when I was 19 and got married at the end of the next year. My first child was born in 1919, the second in 1920, and the third in 1921. However, because my husband was weak, there wasn't any other way but for me to work at the mine. My mother and little sister came to babysit from my hometown and I became the bread winner to feed a family of five. (Tajima 2000: 139)

The stories of the women reflect the conditions in which they lived and worked - their habitus (Bourdieu 1990). Immersed in the culture of the mines, in the intricate social networks of life in the mines, and in the coalmining villages (tanju), many women were able to step into working the seams with professionalism and commitment. Many also experienced alienation, physical assault, psychological domination, and bullying by both men and women. But they were always known to each other, and they were known to the men as well. Their engagement with each other extended to their daily lives away from the pit as members of families, clubs, groups, and organisations.

Tajima's evocative Tanko Bijin (2000), a sensitively written biographical narrative illustrated with deftly shot black and white portraits of women coalminers, articulates these relationships with skill and sympathy. In his interviews with many coalmining women the theme of a continuing and permanent struggle for existence is common. This is not expressed in a critical way; rather, their engagement with their harsh lives is

\footnotetext{
${ }^{6}$ Women generally worked for a percentage of men's wages, in some cases up to roughly 80 percent of the men's pay, based on piecework recovery of coal. This pay, however, was a considerable improvement on pay for hauling and sorting.
} 
invariably spoken of positively as though it is somehow 'character building.' Perhaps more importantly, their work in the mines was seen as an inescapable part of life, just as their roles as 'good wives, wise mothers' were never challenged. Women in the mines were, it appears, genuine superwomen, capable of meeting whatever challenges were thrown at them.

Arguably, then, the embeddedness of the women in the culture, and the fact that this was overlooked by occupation authorities, is significant. The prospect of not working in the mines was so alien to most women miners that it was unthinkable. As we see below, when circumstances became more dire for the state, for the company, for management, and for women themselves, then they cooperatively participated in the workforce, even though many knew it was a temporary arrangement. Yet, brought in to address a perceived temporary labour shortage, women were not content to be made redundant the moment an occupying government dictated it should happen. Socialised within the habitus of the coalmining lives, women continued to play an integral and profound role in Japanese coalmines throughout the 1930s and 1940s.

\section{The end of the war}

After the atomic bombings of Hiroshima and Nagasaki, the Japanese state surrendered in August 1945. Following the declaration by the Emperor of Japan's unconditional surrender, the Supreme Commander of the Allied Powers (SCAP)—Douglas MacArthur during the Allied Occupation; note that SCAP also refers to the various occupation offices under MacArthur and his successors - decreed that Japan would be responsible for providing reparations to those countries it had damaged during its fifteen year war. The few surviving factories were dismantled, and infrastructure was loaded onto ships and exported to China and Southeast Asia as part of a punitive policy on the part of the US Occupation authorities (SCAPIN 1945: 378). While SCAP was clear that it was focused on dismantling only the factories of the zaibatsu, and those industries that could be construed as relating to war, breaking up manufacturing enterprises had a severe knock-on effect on the coal industry.

Already stricken by massive labour shortages, the industry was in severe decline in the months following the declaration of surrender. The larger companies effectively closed down operations, while the smaller companies maintained their operations at a vastly reduced pace. A shortage of coal resulted. This was problematic for SCAP authorities: 
on the one hand, they were focused on dismantling the infrastructure that had led to Japan's military aggression; on the other hand, they were aware that industry needed to be rebuilt in order for Japan to mature as a peaceful economy (Yada 1975). And driving this conundrum was Japan's only source of competitive locally available energy-coal.

When the Japanese Emperor announced the end of hostilities in August 1945, the coalmines faced an uncertain future. What they could be sure of, however, was that their industry would not remain the same. Colonial voluntary and forced labourers and POWs would be repatriated. The economy was in ruins, and the need for coal was debatable immediately after the war. Production was shut down until SCAP announced its intentions for the nation's economic recovery. There was even talk in 1945 of nationalising the coal industry, after its position as central to the economic welfare of the nation was established. Once the prioritisation of the coal industry was confirmed on December 7, 1945, (SCAPIN 398), the smaller coalmines pushed their production capacity to exceed wartime levels. Instrumental in this push were women - specifically those employed as diggers, haulers, and sorters.

\section{Getting around SCAP's regulations}

Following the prioritisation proclamation, the smaller mines stepped up production, primarily by delaying the repatriation of Korean and Chinese labour, and retaining the labour of women on the coalface (interviews with Sasaki and Sato, 1988). Many women who had worked on the coalface needed to keep their incomes as miners in the years after the war. And the companies needed to retain the skilled labour of the women.

At the end of 1947, however, the Occupation declared that women were no longer allowed down the mines. This was to 'protect' them from the inequities of a difficult and dirty occupation. While, on the one hand, introducing women's rights as a fillip for the new constitution was hastily put together to apply to the nation, on the other hand, the Occupation's preoccupation with protecting women from themselves had two important consequences. First, it was applied quickly to all large coal companies in Japan, and second, the smaller companies conspired with their women miners to deceive the Occupation authorities and their agents in the region.

In a widespread, apparently spontaneous, response to MacArthur's proclamation, women changed their names to male ones on the company registers, and continued to 
work as coalface diggers (Idegawa 1984). This process of nominal gender alteration was a subtle form of subversion by women miners who were otherwise disempowered in relation to the means of production. By changing their names on the registers of small companies they continued working as primary breadwinners, and with the complicit knowledge of the companies. There were precedents for this misrepresentation: children often appropriated their mothers' names, as we have seen, to lie about their age; and, representing oneself as male was not a particularly big leap of consciousness.

According to Idegawa, a local historian researching Japanese women's working lives in this epoch, companies also contrived to represent women as men so as to cheat auditors. Many women who worked throughout the war were senior workers, with long experience at the coalface. They were productive and physically strong, were trained in specific skills, and had long corporate experience (interview with Idegawa, 2009). From the corporate perspective, then, women were competent and talented, were cheaper to employ, less likely to become involved in physical violence, and worked harder than men (interview with Nomi, 1988).

The companies, therefore, saw this gender dissimulation as an acceptable means of dealing with a labour shortage, while complying with government regulations. So, while the circumstances for the women who worked in the mines were difficult - the so-called 3K referred to by Tajima (2000: vi) ${ }^{7}$ —working on the coalface was a choice women made, supported by management, who came together as 'strange bedfellows' in a convenien' arrangement. For the women, the arrangement provided better pay than sorting coal, and given that many women were rendered primary bread-winners in their families due to the absence of the men, they were pleased to work harder and take the higher wages, even if the salaries were not on a par with men's. For their part, the companies received a double benefit; their workforce wasc ompliant, competent, energetic, and disciplined; and companies saved twenty percent on each woman miner who went down the shaft.

In contrast to the small-medium sized companies operating outside of public scrutiny, the larger companies - the zaibatsu, in particular - restricted women's labour to sorting

\footnotetext{
${ }^{7}$ The '3-k' refers to kitanai, kitsui, kiken (dirty, difficult, dangerous) work. This work was usually the province of minorities or disadvantaged subaltern people, and was introduced into the lexicon in the 1980 s to describe the work undertaken by migrant and other workers in Japan.
} 
coal at the pit top. Driven by a series of government ordinances after 1945, they were closely audited by the state to ensure that the directives issued by SCAP, or SCAPINs as they were known, were acknowledged and responded to (Sonoda 1970). In other words, although company practices and procedures restricted the employment of women across the mining sector, the state only influenced the compliance of larger mining companies with its labour ordinances.

And this, indeed, is the point of this essay. While official rhetoric had SCAP legislating women out of the mines - for their 'own good,' and in line with Article 14 of the 1947 Constitution - in practice, women worked in the mines regardless of such edicts. There was collusion in smaller companies from remote areas. There the power of state discourse was diluted by regional practices informed by long histories of independent and uncontrolled management behaviour, hence regions were marked as of the 'Wild West' (interview with Sasaki 1988). Indeed, given that police were marginalised, it is unsurprising that companies ignored state mandates concerning mining safety, labour practices, or production targets (see Allen 2009). Women were seen as a human resource, and with their tacit consent, resistance to the demands of the state was manufactured through the twin deceit of either falsifying employment records to record women as men on the roster, or by ensuring that the false records were transmitted to interested authorities who lacked the logistic capacity to investigate and audit the smaller mines. Such practices had long historical precedents, and reflect the difficulties involved in imposing new regulations on extant management cultures, already wedded to systems of control based on physical intimidation, corrupt management, and Panopticon-like means of surveillance.

\section{Conclusion}

Assessing the influence of the Japanese surrender, and the subsequent US Occupation, on women miners, renders immediately apparent the difference between the rhetoric of the Occupation, which emphasised democracy, industrial advancement, and human rights (including women's rights), and what transpired on the ground in areas beyond the reach of the Occupation forces. In remote areas, where communication from Tokyo was sporadic at best, illiteracy and innumeracy were rife, and education largely overlooked during the war years, news of the Occupation's edicts, and of significant policy changes, slowly permeated Japanese society. 
A second theme is the agency of women in resisting Occupation edicts, largely to further their own interests. Historically involved in small and medium sized mines since Japanese mining's earliest industrialisation, women had a vested interest in the industry's survival. Faced with the option of being made redundant or deceiving the state by representing themselves as male in order to work, many women chose the latter course. While it is clear that during the war women in general were discriminated against economically, socially and in respect to work, marriage, and education, women in the coalmines experienced different, often physical forms of, discrimination and parochialism. Yet, they were also accorded respect. Coal working traditions, particularly in the small mines, reinforced the perception that it was unnecessary to concede to outsiders' perceptions of women's roles, for differential structures reinforced by unwritten and draconian rules operated in the coal communities.

Crucial, here, was the structure of the coal companies. In the small-medium sector, notably, company management eschewed lip service to tenets of social conformity within the mainstream Japanese population. Indeed, in order to retain profitability and high production, many companies were run in ways that were regarded as violent, with thugs controlling the labour force that oversaw production. By handing over control of labour to such agencies, the coal companies both elided their own responsibility to respond to requests and demands from workers for safe working environments, and passed on the effective running of the coal face to groups of misogynistic, conservative and violent men. Some Coalmining regions, because of their 'frontier' character, operated steadfastly beyond the reach of authorities, regardless of whether they were Japanese or Occupation.

While the US-dominated Occupation sought to impose on Japanese populace principles that were seen to be universal, they were in fact highly ethnocentric. Many of the tenets that the Occupation framed and implemented as law were alien to the Japanese people. Tied to this concept was the invocation of what Dower has referred to as the 'victor's justice' that was a central empowering platform of Occupation policy (1986). That is, because Japan was so comprehensively defeated, the USA could dictate to Japan whatever terms it wanted. As political circumstances, both international and domestic, changed, and in turn influenced policy-making, it is unsurprising that the Occupation wielded what appeared to Tokyo to be almost unlimited political power. However, there 
was a significant difference between the rhetoric of the Occupation and its on-theground practices. In the 'frontiers' women defied MacArthur's mandate that women not work in the mines. Until the early 1950s, in fact, many hundreds of women laboured at the coalface despite the proscriptions (Idegawa, interview 2009). This occurred because the activities of small-medium companies eluded the gaze of the administratively stretched Occupation authorities. Subsequently, these mines in the 'frontiers' continued with their wartime power structures intact.

Women's position in the account above is contingent. Offered an opportunity to embrace equal rights, and to have access to all that a rebuilt state could offer under a benign autocracy, some women left the workforce. Others kept working under false names in an unstable economic environment, where no-one's future was certain. At least work would provide them and their relatives with food, it was reasoned. At the vanguard of resistance to Occupation dictates, women were neither simply resistant nor victims of political expediency, even if their position reinforced existing power structures within the coalfields.

The Occupation of Japan after the end of the Second World War engendered an ethnocentric and dominant web of power relations. Unsurprisingly, Occupation forces seemed to believe their own propaganda about humanitarian interventions, benevolent dictates, and democratic processes - with some justification. Japan was rapidly becoming 'Americanised.' While strongly motivated to ensure that human rights were passed on to those the US Allies had bombed into submission, those Allies were reliant on existing Japanese modes of communication to ensure that order was restored and maintained. The isolation of the mines, their long histories of repressive labour control, and their reluctance to acknowledge the legitimacy of any authority - whether Japanese or US - ensured that control measures designed in Tokyo were slow to permeate the Chikuhō area. Resistance to the Occupation imperative to remove women from the mines was profound enough that, like the cases of resistance in Scott's Weapons of the Weak, ${ }^{8}$ grass roots duplicity between women, who wanted to continue working in the mines, and management, contributed to a form of passive resistance to the state. The 'energy revolution' of the 1950s, and cheap exports from Australia and China, led

\footnotetext{
${ }^{8}$ James Scott's Weapons of the Weak is a seminal text that describes how resistance to power can often be framed in small, everyday forms of resistance: slowing the pace of work, talking and chatting, underperforming, but all done in ostensibly passively supporting ways.
} 
to the decline of the industry, and by the end of the 1950s the issue of women miners had become irrelevant as the industry as a whole tried to survive. With the decline of the industry came a decline in the power of the coal companies, and as their economic circumstances deteriorated, their capacity to control people and information flows to the region similarly declined. In the context of rapidly increasing mining unemployment among men, women miners were soon replaced on the coalface, a situation that continued until the closure of the mines in the 1950s and early 1960s.

In the end, the dictates of the Occupation concerning women miners were adhered to, even in the remote coal producing regions. But this was not because of the power of Occupation authorities. Rather, it was because historical, culturally specific economic and social circumstances created the conditions that made the removal of women's labour a practical, though short-term, solution to a larger labour issue. Just as women became involved in the coal industry through economic necessity, the processes of acculaturation into the coalmining habitus that impelled their resistance to giving up work on the coalface were linked to the same factors. Culturally embedded, women remained resistant to irrational demands from the state, regardless of whether the incumbent authority was US Occupier or Japanese.

\section{Acknowledgements}

This essay benefited from interviews with the following people: Idegawa Hideko, Kurate-machi, 2009; Nomi Setsuko, Tagawa-shi, 1988; Sasaki Ryuzo, Tagawa-shi, Mitsui Ita, 1988; and, Sato Hideki, Kawasaki-machi, 1988.

\section{Reference List}

Allen, M. 2009, Undermining the Japanese Miracle: Work and Conflict in a Coalmining Community. Cambridge University Press, London.

Bourdieu, P. 1990, In Other Words: Essays Towards a Reflexive Sociology Cambridge: Polity Press, 1990.

Dower, J. 1986, War Without Mercy: Race and Power in the Second World War. Pantheon, New York. 1999, Embracing Defeat: Japan in the Wake of World War II. W.W. Norton \& Company, New York.

Idegawa Hideko. 1984, Hino unda hahatachi: jokojo kara no kikisho (Mothers Who Gave Birth to Fire: stories from women miners). Yoshishobo, Kukuoka.

Idegawa Hideko. 2005, Onnatachi no Chikuhō: Kuwaetai yama no roumi to karashi (Women's Chikuhō: Life and work in the exploitative mines). Jinken, Fukuoka.

Samuels, R. 1987, The Business of the Japanese State: Energy Markets in Comparative and Historical Perspective. Cornell University Press, Ithaca.

SCAPIN (Supreme Commander for the Allied Powers, Directives to the Japanese Government). 1945

(2007), Record Group 331s. Available, online: www.ndl.go.jp/jp/data/kensei_shiryo/senryo/pdf/ SCA_1.pdf [Accessed 1 June, 2010].

Scott, J. 1985, Weapons of the Weak: Everyday Forms of Peasant Resistance. Yale University Press, Yale. Sone Sachiko. 2007, 'The Reversible World of Japanese Coalmining Women.' The Australian Journal of Anthropology, vol. 18, no. 2, 207-22. 
Sonoda Minoru. 1970, Sengo Sekitan-shi (A History of Postwar Coal). Sekitsu, Fukuoka. Tajima Masami. 2000, Tanko Bijin (Coalmining Beauties). Tsukiji Sokan, Tokyo. Ueno Eishin. 1985, Naraku no Seiun (The Nebula of Hell). Keishobo, Tokyo.

Yada Toshifumi. 1975, Sengo nihon no sekitan sangyo (The Postwar Japanese Coal Industry). Shinhyoron, Tokyo. 